\title{
MicroRNAs in Colorectal Cancer: from Diagnosis to Targeted Therapy
}

\author{
Ayla Valinezhad Orang ${ }^{1}$, Abolfazl Barzegari ${ }^{2 *}$
}

\begin{abstract}
Colorectal cancer (CRC) is one of the major healthcare problems worldwide and its processes of genesis include a sequence of molecular pathways from adenoma to carcinoma. The discovery of microRNAs, a subset of regulatory non-coding RNAs, has added new insights into CRC diagnosis and management. Together with several causes of colorectal neoplasia, aberrant expression of oncomiRs (oncogenic and tumor suppressor miRNAs) in cancer cells was found to be indirectly result in up- or down-regulation of targeted mRNAs specific to tumor promoter or inhibitor genes. The study of miRNAs as CRC biomarkers utilizes expression profiling methods from traditional tissue samples along with newly introduced non-invasive samples of faeces and body fluids. In addition, miRNAs could be employed to predict chemo- and radio-therapy responses and be manipulated in order to alleviate CRC characteristics. The scope of this article is to provide a comprehensive review of scientific literature describing aberrantly expressed miRNAs, and consequently dysregulation of targeted mRNAs along with the potential role of miRNAs in CRC diagnosis and prognosis, as well as to summarize the recent findings on miRNA-based manipulation methods with the aim of advancing in anti-CRC therapies.
\end{abstract}

Keywords: Colorectal cancer - microRNA - biomarker - cancer therapy

Asian Pac J Cancer Prev, 15 (17), 6989-6999

\section{Introduction}

Colorectal cancer (CRC) is still one of the five most leading cancer-related death which have one million new cases every year (Pourhoseingholi, 2012; Siegel et al., 2012). Although since mid-1980's the number of CRCrelated death has been decreasing due to the increased awareness and progresses in screening approaches, the prognosis of patients with metastatic CRC remains unknown (Terzic et al., 2010; Salimzadeh et al., 2012). Eventually, the study for early diagnosis and prognosis markers are still crucial and would allow selecting patients with early CRC stages for operative cancer management and developing novel targeted therapies.

The involvements of non-coding RNAs in carcinogenesis and tumor progression have been confirmed by numerous functional studies in the past decades (Seton-Rogers, 2013). Among the all types of ncRNAs, microRNAs (miRNAs) received the greatest attention due to their frequent dys-regulations in CRC. miRNAs compromise a large subsequent of endogenous small ncRNAs that regulate gene expression posttranscriptionally and control various cellular mechanisms including tissue development (Johnston and Hobert, 2003; Zhao et al., 2005), cell proliferation (Cheng et al., 2005; 2006), cell division (Hatfield et al., 2005; Croce and Calin, 2005), cell differentiation (Naguibneva et al., 2006), neuronal asymmetry (Bartel, 2004), metabolism (Filipowicz, 2005), stem cell properties (JamshidiAdegani et al., 2014), apoptosis (Matsushima et al., 2011), protein secretion (Poy et al., 2004) and viral infection (Mollaie et al., 2013). Each individual miRNA predicted to target multiple mRNAs based on the seed sequence matches in their 3'-UTRs and vice versa a single mRNA may be targeted by several miRNAs and have diverse outcomes (Lewis et al., 2005). Therefore, perturbation in miRNA expression may result in facilitating tumor initiation and proliferation and/ or inhibiting proliferation and invasion through targeting various mRNAs (Ahmed et al., 2009; Bandres et al., 2009a).

miRNAs have been reported to have pervasive effects on CRC tumorigenesis including, oncogenesis, progression, invasion, metastasis, and angiogenesis (Esquela-Kerscher and Slack, 2006; Huang et al., 2008; Zhang et al., 2012). Nevertheless, a comprehensive understanding of the functional role and thorough panel of target mRNAs for individual miRNAs are still in their infancy. Equally challenging or even more challenging is their applications in CRC diagnosis and prognosis, since clinical application of miRNAs have some drawbacks and some provocative reports directly contradict one or another outcomes of original assertions.

${ }^{1}$ Department of Animal Biology, Faculty of Natural Sciences, The University of Tabriz, ${ }^{2}$ School of Advanced Medical Sciences, Research Centre for Pharmaceotical Nanotechnology, Tabriz University of Medical Sciences, Tabriz, Iran *For correspondence: barzegaria@tbzmed.ac.ir 


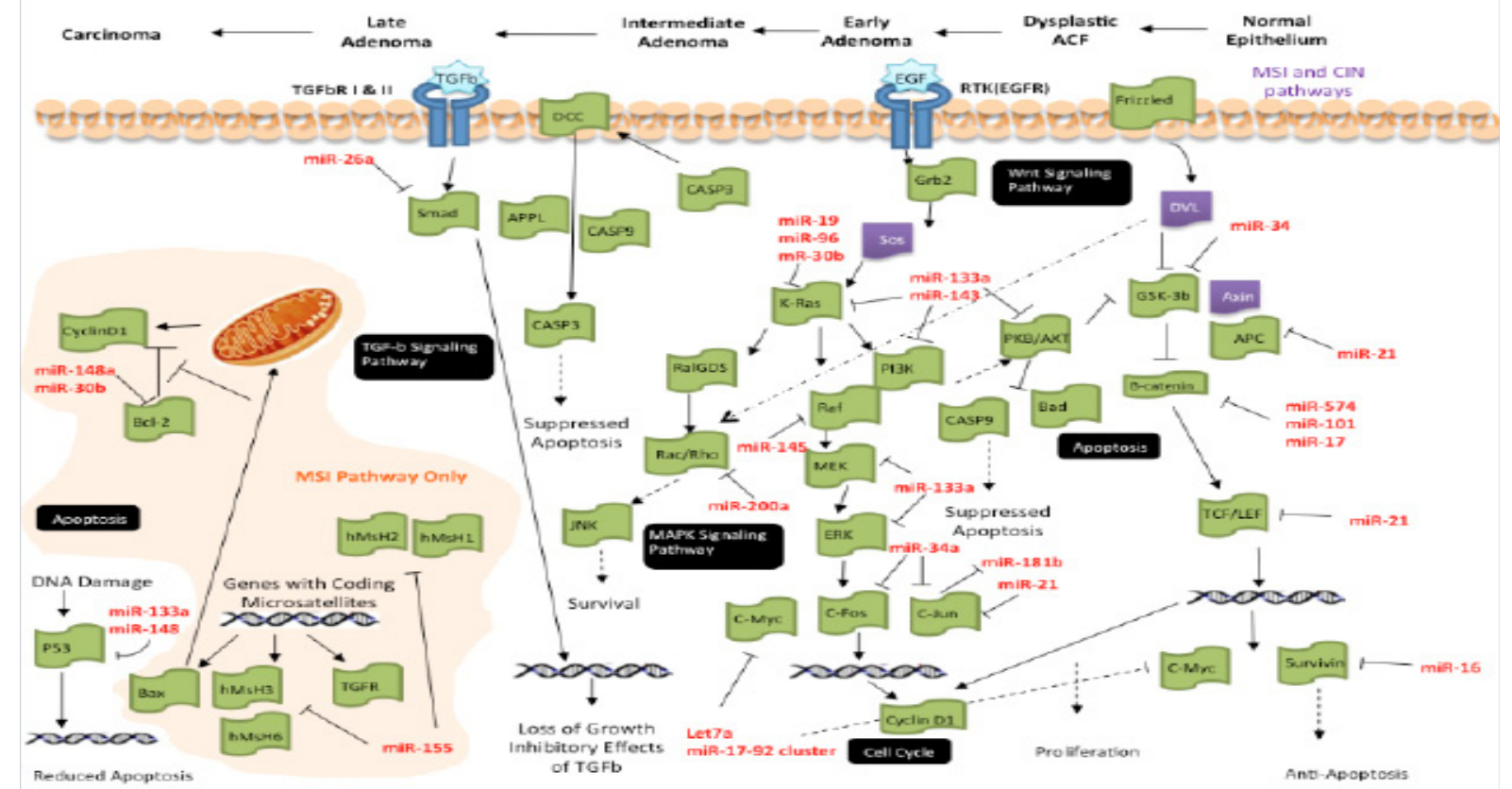

Figure 1. Regulation of CRC-Related Pathways by miRNAs. According to Vogelstein's model Colorectal cancer pathogenesis includes sequence of changes and mutations in normal epithelium from dysplasia to carcinoma. Several miRNAs have been reported to regulate the Wnt, TGF-b, and MAPK signalling pathways, along with cell cycle and apoptosis through direct and indirect mechanisms

These discrepancies between studies could be explained by different factors. First, the heterogeneities observed in results arise from different tumor locations (Colon or Rectum, proximal or distal colon tumor) (Slattery et al., 2011). Secondly, different population sampling bearing various genomic pools could lead to different gene expressions and regulations. Therefore, miRNA expression pattern could differ among populations. On the other hand, the subgroup of tumor is an important defining factor since it has been reported that miRNA deregulation could vary between MSI and CIMP tumors (Schepeler et al., 2008; Earle et al., 2010; Haghighi et al., 2010; Shemirani et al., 2011). In addition, several other factors affect miRNA expression profiling and may hand in different data and results. These factors include the type of the sample (blood, tissue, serum, and faces), the timing between sampling and extraction, methods and kits used for profiling experiments and sample storage.

Despite all aforementioned disadvantages, accumulating proofs demonstrating the potential role of miRNAs in carcinogenesis reflect the worthy advantages of miRNA implications as tumor markers and their potential role for cancer therapies. These advantages include the need of a small amount of sample, the possibility of extracting miRNAs from body fluids, their stability in FFPE tissues, and non-invasive and poisonousness nature of their sampling methods. In the following, we provide a comprehensive review of scientific literature describing the aberrantly expressed miRNAs, and consequently dysregulation of targeted mRNAs along with the potential role of miRNAs in CRC diagnosis, prognosis, and response prediction. We also summarize the recent findings on miRNA-based manipulation methods with the aim to enhance knowledge of anti-CRC therapies.

\section{Clinical Applications}

\section{Cancer diagnosis}

CRC diagnosis based on a molecular signature implies that a specific expression level is found in tumour cells compared to non-tumour counterpart. Increasing profiling experiments have revealed that miRNA expression patterns are unique to specific cancers, unlike other markers currently available, offering capability of cancer diagnosis in early stages (Zhou et al., 2013a; Li et al., 2014c). The most extensively applied techniques of studying miRNA profiles are microarray, real- time PCR- based methods, as well as sequencing and in situ hybridization (ISH) (Weng et al., 2010; Xie et al., 2011). Next Generation Sequencing (NGS) added a new layer of accuracy as new method for miRNA expression measurement and normalization and provided new knowledge of changes in genome and relevant disease for translational studies (Yadav et al., 2014).

The first miRNAs found to be aberrantly expressed in CRC were miR-143 and miR-145 that were consistently downregulated at the adenomatous and cancer stages of CRC neoplasia compared to normal colon mucosa (Michael et al., 2003; Akao et al., 2006b). Since then the literature dedicated to dysregulation of miRNAs in three different series including tumour samples, both fresh frozen and formalin-fixed paraffin-embedded (FFPE), circulating miRNAs, both in serum and plasma, and faecal samples has grown considerably.

Dysregulated miRNAs in tissue samples and CRC cell lines

After discovering miR-143 and miR-145, several studies have been performed in order to investigate other CRC-related miRNAs. miR-143 was then found to be down-regulated in colon but not in rectum related cancer 
DOI:http://dx.doi.org/10.7314/APJCP.2014.15.17.6989

MicroRNAs in Colorectal Cancer: from Diagnosis to Targeted Therapies

Table 1. A Comprehensive List of Dysregulated miRNAs in Colorectal Cancer Tissues and Cell Lines

\begin{tabular}{|c|c|c|c|}
\hline miRNA & Dysregulation & Predicted target genes & References \\
\hline$\overline{\text { Let-7a }}$ & Down & c-Myc, DLD1, KRAS & (Cummins et al., 2006, Akao et al., 2006a, Fang et al., 2007, Earle et al., 2010) \\
\hline Let-7c & Down & MMP11, PBX3 & (Han et al., 2012) \\
\hline Let-7g & Up, Down & $\begin{array}{l}\text { KRAS,MYS,E2F,CYC-1, HRAS,HMGA2, } \\
\text { NF2, CCND, }\end{array}$ & (Akao et al., 2006a, Xi et al., 2007, Vogelstein et al., 1988) \\
\hline miR-1 & Down & MET & (Reid et al., 2012) \\
\hline $\operatorname{miR}-7$ & Down, up & XRCC2, YY1,PAX6, & (Motoyama et al., 2009, Xu et al., 2014, Zhang et al., 2013c, Li et al., 2014b) \\
\hline $\operatorname{miR}-9$ & Down & $\alpha$-Catenin & (Cekaite et al., 2012, Zhu et al., 2012) \\
\hline miR-10b & Down & & (Nishida et al., 2012, Burk et al., 2008, Zhu et al., 2012) \\
\hline miR-16 & Down & $\mathrm{Cdx} 2$ & (Ma et al., 2013, Volinia et al., 2006, Tagawa et al., 2012) \\
\hline $\operatorname{miR}-17$ & Up & THBS1, MYC, CDKN1A,TMBIM1, E2F1 & $\begin{array}{l}\text { (Lanza et al., 2007, Arndt et al., 2009, Volinia et al., 2006, Motoyama et al., 2009, } \\
\text { Diosdado et al., 2009, Cummins et al., 2006) }\end{array}$ \\
\hline miR-18a & Up & ATM & $\begin{array}{l}\text { (Cummins et al., 2006, Sarver et al., 2009, Arndt et al., 2009, Wang et al., 2010, } \\
\text { Wu et al., 2013a) }\end{array}$ \\
\hline $\operatorname{miR}-19 \mathrm{a}$ & Up & TF & (Diosdado et al., 2009, Yu et al., 2013a, Bandres et al., 2006, Cummins et al., 2006) \\
\hline miR-19b & Up & SFPQ and MYBL2 & (Cummins et al., 2006, Arndt et al., 2009, Kurokawa et al., 2012) \\
\hline $\operatorname{miR}-20 \mathrm{a}$ & Up & PTEN, TMP1 & $\begin{array}{l}\text { (Tan et al., 2013, Bovell et al., 2013, Earle et al., 2010, Yantiss et al., 2009, } \\
\text { Volinia et al., 2006) }\end{array}$ \\
\hline $\operatorname{miR}-20$ & Up & & (Bandres et al., 2006, Lanza et al., 2007, Earle et al., 2010) \\
\hline $\operatorname{miR}-21$ & Up & $\begin{array}{l}\text { PTEN, BCL2, PDCD4, CDC25A, TIMP1, } \\
\text { SPRY2, SERPINB5, RECK, TIMP3, } \\
\text { TIAM1, MSH2, MSH6 }\end{array}$ & $\begin{array}{l}\text { (Asangani et al., 2008, Schetter et al., 2008, Valeri et al., 2010a, Slattery et al., } 2011 \\
\text { Arndt et al., 2009, Kulda et al., 2010, Yamamichi et al., 2009) }\end{array}$ \\
\hline $\operatorname{miR}-23 \mathrm{a}$ & Up & MTSS1 & (Rossi et al., 2007, Jahid et al., 2012) \\
\hline $\operatorname{miR}-23 b$ & Down & & (Volinia et al., 2006) \\
\hline miR-24 & Down & DHFR & (Michael et al., 2003, Mishra et al., 2009) \\
\hline $\operatorname{miR}-25$ & Up & & (Lanza et al., 2007, Earle et al., 2010, Xi et al., 2007) \\
\hline miR-26a & Down & & (Michael et al., 2003) \\
\hline $\operatorname{miR}-27 \mathrm{a}$ & Up & KITENIN & (Rossi et al., 2007, Park et al., 2014) \\
\hline $\operatorname{miR}-27 b$ & Up & & (Rossi et al., 2007) \\
\hline miR-26b & Down & & (Earle et al., 2010) \\
\hline $\operatorname{miR}-29 \mathrm{a}$ & Up & KLF4 & (Tang et al., 2014) \\
\hline $\operatorname{miR}-29 b$ & Up & MMP-2 & (Poudyal et al., 2013) \\
\hline $\mathrm{miR}-30 \mathrm{a}$ & Down & DTL, PIK3CD & (Baraniskin et al., 2012, Zhong et al., 2013) \\
\hline $\mathrm{miR}-30 \mathrm{~b}$ & Down & KITENIN & (Park et al., 2014) \\
\hline $\mathrm{miR}-30 \mathrm{c}$ & Down & RASA1, ERG, SEMA6D, SEMA3A & (Xi et al., 2007, Volinia et al., 2006, Cummins et al., 2006) \\
\hline $\mathrm{miR}-30 \mathrm{e}$ & Up & HELZ, PIK3C2A & (Rossi et al., 2007, Schepeler et al., 2012) \\
\hline $\operatorname{miR}-31$ & $\mathrm{Up}$ & TIAM1, FOXC2, FOXP3, HIF1A, FIH1 & (Chen et al., 2014b, Cottonham et al., 2010, Earle et al., 2010, Olaru et al., 2011) \\
\hline $\operatorname{miR}-32$ & Up & PTEN & (Wu et al., 2013b) \\
\hline $\operatorname{miR}-33$ & Up & GABRB2 & (Narasimhan., 2014) \\
\hline $\operatorname{miR}-34$ & Down & AXL & (Mudduluru et al., 2011) \\
\hline miR-92a & Up & DKK-3, BCL-2 & (Yamada et al., 2013, Tsuchida et al., 2011) \\
\hline miR-93 & Down & $\begin{array}{l}\text { HDAC8, TLE4, ERBB2, } \\
\text { p21, VEGF }\end{array}$ & (Yu et al., 2011, Yang et al., 2012) \\
\hline miR-95 & Up & Nexin1 & (Huang et al., 2011) \\
\hline miR-96 & Up & & (Xu et al., 2012b) \\
\hline miR-101 & Down & EP4R & (Chandramouli et al., 2012) \\
\hline miR-106a & Up & PTEN, E2F1, RB1, TGFBR2 & (Catela Ivkovic et al., 2013, Feng et al., 2012, Diaz et al., 2008) \\
\hline $\operatorname{miR}-106 b$ & Up & $\mathrm{p} 21 / \mathrm{CDKN} 1 \mathrm{~A}$ & (Ivanovska et al., 2008) \\
\hline miR-107 & Up & DAPK and KLF4 & (Chen et al., 2012b) \\
\hline $\mathrm{miR}-124 \mathrm{a}$ & Down & PRRX1, MYH9 and SOX9 & (Zhang et al., 2014b, Park et al., 2014) \\
\hline miR-125a & Down, Up & p53 & (Nishida et al., 2011) \\
\hline miR-126 & Down & IRS-1 & (Zhou et al., 2013b) \\
\hline miR-127 & Up & BCL6 & (Saito et al., 2006) \\
\hline miR-133a & Down, Up & LASP1, KRAS & (Wang et al., 2013) \\
\hline miR-133b & Down & Met, TBPL1 & (Hu et al., 2010, Xiang and Li, 2014) \\
\hline $\operatorname{miR}-135 \mathrm{a}$ & Up & MTSS1 & (Zhou et al., 2012) \\
\hline miR-135b & Up & TGFRB2, DAPK1, APC, FIH, LATS2 & (Valeri et al., 2014, Ragusa et al., 2012) \\
\hline miR-137 & Down & CDC42, LSD1 & (Liu et al., 2011b, Balaguer et al., 2010) \\
\hline miR-138 & Down & TWIST2 & (Long et al., 2013) \\
\hline miR-139 & Down & IGF-IR, RAP1B & (Guo et al., 2012, Shen et al., 2012) \\
\hline miR-143 & Down & KRAS, MAPK7, DNMT3A, ERK5 & (Chen et al., 2009, Ng et al., 2009b) \\
\hline miR-145 & Down & $\begin{array}{l}\text { TGFBRE, APC, IRS1, STAT1, YES1, } \\
\text { FLI1, RAS, c-Myc, SOX52 }\end{array}$ & (Arndt et al., 2009, Shi et al., 2007, Akao et al., 2006b) \\
\hline miR-147 & Up & & (Rossi et al., 2007) \\
\hline $\mathrm{miR}-148 \mathrm{a}$ & Down & TGIF2, Bcl-2 & (Lujambio et al., 2008, Zhang et al., 2011a) \\
\hline miR-151 & Up & & (Rossi et al., 2007) \\
\hline miR-152 & Up & & (Rossi et al., 2007) \\
\hline $\operatorname{miR}-155$ & Up & MSH2, MSH6, MLH1, Claudin-1, E2F2 & (Zhang et al., 2013a, Li et al., 2014a, Valeri et al., 2010b) \\
\hline miR-181 & Down & & (Pichler et al., 2014, Nakajima et al., 2006) \\
\hline miR-182 & Up & TSP1 & (Amodeo et al., 2013) \\
\hline miR-183 & Up & EGR1 & (Zhou et al., 2014, Sarver et al., 2010) \\
\hline miR-185 & Up & RhoA, Cdc42 & (Rossi et al., 2007, Akcakaya et al., 2011, Liu et al., 2011a) \\
\hline miR-191 & Up, Down & TIMP3 & (Qin et al., 2014, Xi et al., 2006, Earle et al., 2010) \\
\hline miR-192 & Down & CDKN1A, DHFR, Bcl-2, Zeb2, VEGFA & (Braun et al., 2008, Song et al., 2008, Geng et al., 2013) \\
\hline miR-195 & Down & BCL2 & (Wang et al., 2012c, Liu et al., 2010) \\
\hline miR-196a & Up, Down & HoxA7, HoxB8, HoxC8 and HoxD8 & (Schimanski et al., 2009, Earle et al., 2010) \\
\hline $\operatorname{miR}-199 \mathrm{a}$ & Down & AXI & (Mudduluru et al., 2011) \\
\hline miR-200 family & Up, Down & SOX2, ZEB1, PTEN, ETS1, FLT1, & (Lu et al., 2014, Chen et al., 2008, Chen et al., 2014a, Hur et al., 2013) \\
\hline miR-203 & Down, Up & ATM, AKT2 & (Chiang et al., 2011, Zhou et al., 2014, Li et al., 2011) \\
\hline miR-205 & Down, Up & & (Orang et al., 2014b) \\
\hline miR-210 & Down & VMP1 & (Rossi et al., 2007, Qu et al., 2014) \\
\hline miR-215 & Down & DTL & (Karaayvaz et al., 2011) \\
\hline miR-218 & Down & BMI1 & (Yu et al., 2013b, He et al., 2012) \\
\hline miR-221 & Up & PTEN & (Pu et al., 2010) \\
\hline
\end{tabular}




\begin{tabular}{llll}
\hline miRNA & Dysregulation & Predicted target genes & References \\
\hline miR-222 & Up & PTEN, ADAM-17 & (Tsunoda et al., 2011, Xu et al., 2012a) \\
miR-223 & Up & FOXO1, IGF-1R & (Wu et al., 2012b, Josse et al., 2014) \\
miR-224 & Up, Down & MBD2 & (Zhang et al., 2013b, Yuan et al., 2013) \\
miR-296 & Down & & (Kunte et al., 2012) \\
miR-320 & Up & & (Schepeler et al., 2008) \\
miR-342 & Down & DNMT1, EVL & (Grady et al., 2008, Wang et al., 2011) \\
miR-372 & Up & TXNIP & (Yamashita et al., 2012, Ragusa et al., 2012) \\
miR-375 & Down & PIK3CA & (Cummins et al., 2006, Sarver et al., 2009) \\
miR-378 & Up, Down & Vimentin & (Sarver et al., 2009, Wang et al., 2010, Arndt et al., 2009, Zhang et al., 2014a) \\
miR-422a & Down & & (Arndt et al., 2009) \\
miR-451 & Down & COX-2, CAB39, LKB1, AMPK, AKT, PI3K and Bcl2 & (Bandres et al., 2009b, Bitarte et al., 2011, Li et al., 2013) \\
miR-497 & Down & IGF1-R & (Guo et al., 2013) \\
miR-622 & Up & & (Balaguer et al., 2011) \\
miR-941 & Down & ADAM15 & (Yan et al., 2011) \\
miR-1238 & Up & & (Balaguer et al., 2011) \\
miR-1247 & Down & & (Yan et al., 2011) \\
\hline
\end{tabular}

and it acts as a tumour suppressor by inhibiting KRAS (Slaby et al., 2007; Chen et al., 2009; Motoyama et al., 2009; Wang et al., 2009). Subsequently, high expression levels of miR-21 were found to be correlated with distant metastatic CRC samples and poor survival prognosis and therapeutic outcomes via targeting PDCD4, a tumour suppressor protein (Asangani et al., 2008; Schetter et al., 2008). Let-7 family members that include 14 isomers were of the most studied miRNAs that act as a tumour suppressor through targeting growth suppressors such as RAS and MMP11, and oncogenes such as PBX3 and NIRF (Akao et al., 2006a; Han et al., 2012; Wang et al., 2012a). Another important miRNA is the miR-200 family which found to be associated with metastasis inhibition by targeting the transcriptional repressor zinc-finger E-box binding homeobox 1 (ZEB1) in CRC and shortly after that miR-200c found to be downreglated in CRC cells (Burk et al., 2008; Chen et al., 2012a; 2012c).

Whereas several miRNAs have been found to be over-expressed or under-expressed in CRC samples compared to normal adjacent colorectal tissues, the role of the differentially expressed miRNAs in colorectal tumorigenesis is not fully understood. Moreover, there are some discrepancies between studies that may arise from different factors such as different tumour locations and genetic backgrounds (Schepeler et al., 2008; Slattery et al., 2011). In Table 1, the studies on dysregulated miRNAs and their cognate mRNAs are summarized.

\section{Dysregulated miRNAs in serum or plasma samples}

Recent studies have revealed that dysregulated miRNAs are present in body fluids carried by small micelles and therefore, are protected from hostile ribonuclease activity (Chim et al., 2008; Lawrie et al., 2008; Mitchell et al., 2008). Many groups evaluated the feasibility of using circulating miRNAs as non-invasive biomarkers for CRC (Slattery et al., 2011). Chen et al. reported the existence of circulating miRNA in the serum of CRC patients for the first time (Chen et al., 2008). Since then, dysregulated miRNAs were found to be in plasma or serum of CRC patients at detectable levels and are capable of distinguishing normal samples from CRC samples (Huang et al., 2010; Wang and Zhang, 2012; Wang et al., 2012b; Kanaan et al., 2012). Furthermore, the discovery of miRNA transport, mediated by exosomes, opened a new research area of isolating tissue specific circulating exosome and their contained miRNAs to better analysis of their expression (Taylor and Gercel-Taylor, 2008). These dysregulated circulating miRNAs are summarized in Table 2.

\section{Dysregulated miRNAs in stool samples}

Stool-based test is a widely used non-invasive screening method of CRC patients (Lee et al., 2014). However, due to their poor sensitivity and specificity these tests were losing their significance. Nevertheless, reporting miRNAs as screening markers found in faecal specimens by Ahmad et al in 2009, elevated the practicability of using miRNAs as non-invasive diagnostic biomarkers (Ahmed et al., 2009). Surprisingly, analysed miRNAs in stool samples showed relatively high sensitivity and specificity (Link et al., 2010; Koga et al., 2010; Kalimutho et al., 2011; Li et al., 2012; Wu et al., 2012a). Studies were summarized in Table 3. These studies confirmed the hypothesis that miRNAs hold a potential of being used in a stool-based assay for early CRC detection. However, the capability of profiling such miRNAs for adenomatous polyposis is remained to be explored.

\section{miRNA as Marker for Treatment Response Predictions}

Aberrant expression of some miRNAs has been shown to be associated with treatment response and outcomes in patients with colorectal cancer. An increasing number of dysregulated miRNAs were revealed to have association with drug resistance or sensitivity which indicate their capability of predicting patients' responses to some anticancer agents (Hummel et al., 2010). For instance the upregulated miR-10b and $\mathrm{miR}-192 / 215$ were reported to hold a potential to indicate chemosensitivity to the common 5-FU-based chemotherapy regimen (Boni et al., 2010; Nishida et al., 2012) as well as miR-19a which predicts resistance to FOLFOX chemotherapy in advanced CRC cases (Chen et al., 2013). Pichler et al. showed that miR-18a downregulation is associated with poor survival in patients with CRC and its expression could predict progression-free survival (PFS) in EGFR-targeted therapy (Pichler et al., 2014). Moreover, miR-203 was demonstrated to induce oxaliplatin, a common component 
Table 2. miRNA Dysregulation in Body Fluids

\begin{tabular}{|c|c|c|}
\hline miRNA & Dysregulation & Reference \\
\hline Let-7a & Down & (Wang et al., 2012b) \\
\hline Let-7d & Down & (Hofsli et al., 2013) \\
\hline Let-7e & Up & (Wang et al., 2012b) \\
\hline miR-10a & Down & (Wang et al., 2012b) \\
\hline miR-16 & Up & (Zheng et al., 2013) \\
\hline $\operatorname{miR}-17$ & Up & (Ng et al., 2009a) \\
\hline miR-18a & Up & (Zheng et al., 2013) \\
\hline miR-19a & Up & (Wang et al., 2012b) \\
\hline miR-21 & Up & $\begin{array}{l}\text { (Wang and Zhang, 2012, } \\
\text { Kanaan et al., 2012) }\end{array}$ \\
\hline miR-22 & Up & (Wang et al., 2012b) \\
\hline $\operatorname{miR}-23 a$ & Up & (Chen et al., 2008) \\
\hline $\operatorname{miR}-24$ & Up & (Wang et al., 2012b) \\
\hline miR-29a & Up & $\begin{array}{l}\text { (Hofsli et al., 2013, } \\
\text { Huang et al., 2010) }\end{array}$ \\
\hline $\operatorname{miR}-34 \mathrm{a}$ & Down & (Nugent et al., 2012) \\
\hline $\operatorname{miR}-92 a$ & Up & $\begin{array}{l}\text { (Wang et al., 2012b, } \mathrm{Ng} \text { et al., 2009a, } \\
\text { Hofsli et al., 2013, Pu et al., 2010, } \\
\text { Huang et al., 2010) }\end{array}$ \\
\hline miR-95 & Up & (Ng et al., 2009a) \\
\hline miR-103 & Down & (Hofsli et al., 2013) \\
\hline miR-106a & Down & (Koga et al., 2013) \\
\hline miR-107 & Down & (Hofsli et al., 2013) \\
\hline miR-125 & Up & (Wang et al., 2012b) \\
\hline miR-134 & Up & (Chen et al., 2008) \\
\hline miR-135 & Up & (Ng et al., 2009a) \\
\hline miR-141 & Up, Down & (Wang et al., 2012b, Cheng et al., 2011) \\
\hline miR-143 & Down & (Hofsli et al., 2013) \\
\hline miR-146 & Up & (Chen et al., 2008) \\
\hline $\operatorname{miR}-150$ & Down & (Wang et al., 2012b) \\
\hline miR-151 & Down & (Hofsli et al., 2013) \\
\hline miR-155 & $\mathrm{Up}$ & (Hofsli et al., 2013) \\
\hline miR-188 & Down & (Wang et al., 2012b) \\
\hline miR-191 & Down & (Hofsli et al., 2013, Zheng et al., 2013) \\
\hline miR-192 & Down & (Wang et al., 2012b) \\
\hline miR-199a & Down & (Hofsli et al., 2013) \\
\hline miR-210 & Up & (Wang et al., 2012b, Hofsli et al., 2013) \\
\hline $\operatorname{miR}-221$ & Down & $\begin{array}{c}\text { (Wang et al., 2012b, Chen et al., 2008, } \\
\text { Pu et al., 2010, Hofsli et al., 2013) }\end{array}$ \\
\hline $\operatorname{miR}-222$ & Up & (Chen et al., 2008, Ng et al., 2009a) \\
\hline $\operatorname{miR}-223$ & Up & (Ogata-Kawata et al., 2014) \\
\hline $\operatorname{miR}-224$ & Down & (Wang et al., 2012b) \\
\hline miR-296 & Down & (Shivapurkar et al., 2013) \\
\hline miR-320a & $\mathrm{Up}$ & (Hofsli et al., 2013) \\
\hline miR-376a & Up & (Wang et al., 2012b) \\
\hline miR-378 & Up & (Hofsli et al., 2013) \\
\hline miR-382 & Down & (Hofsli et al., 2013) \\
\hline $\operatorname{miR}-409$ & Down & (Hofsli et al., 2013) \\
\hline $\operatorname{miR}-423-5 p$ & Up & (Hofsli et al., 2013) \\
\hline $\operatorname{miR}-423-3 p$ & Down & (Hofsli et al., 2013) \\
\hline miR-426 & Down & (Wang et al., 2012b) \\
\hline miR-484 & $\mathrm{Up}$ & (Zheng et al., 2013) \\
\hline miR-495 & Down & (Wang et al., 2012b) \\
\hline miR-572 & Down & (Wang et al., 2012b) \\
\hline miR-601 & Down & (Wang et al., 2012b) \\
\hline miR-652 & Down & (Hofsli et al., 2013) \\
\hline $\operatorname{miR}-720$ & Up, Down & (Hofsli et al., 2013, Wang et al., 2012b) \\
\hline $\operatorname{miR}-760$ & Down & (Wang et al., 2012b) \\
\hline
\end{tabular}

combination therapeutic regimen for use in patients with metastatic CRC, and reverse chemoresistance by negatively regulating ATM kinase and Akt, respectively (Li et al., 2011; Zhou et al., 2014).

Besides, experimental and clinical studies have cleared that hsa-let-7g and hsa-miR-181b are potential indicators for chemoresponse to S-1 based chemotherapy and miR-200a, miR-200c, miR-141, and miR-429 expression levels may identify CRC patients, including those with stage II disease, who are most likely to benefit
Table 3. Dysregulated miRNAs Found in Fecal Samples of CRC Patients

\begin{tabular}{lll}
\hline miRNA & Dysregulation & \multicolumn{1}{c}{ Reference } \\
\hline miR-16 & Down & (Ahmed et al., 2009) \\
miR-17 & Up & (Koga et al., 2010) \\
miR-18a & Up & (Koga et al., 2010) \\
miR-19a & Up & (Koga et al., 2010) \\
miR-19b & Up & (Koga et al., 2010) \\
miR-20a & Up & (Ahmed et al., 2009) \\
miR-21 & Up & (Ahmed et al., 2009, Koga et al., 2010, \\
& & Link et al., 2010, Wu et al., 2012a) \\
miR-92 & Up & (Ahmed et al., 2009) \\
miR-92a & Up & (Wu et al., 2012a) \\
miR-96 & Up & (Ahmed et al., 2009) \\
miR-106a & Up & (Ahmed et al., 2009, Link et al., 2010) \\
miR-106b & Up & (Link et al., 2010) \\
miR-125b & Down & (Ahmed et al., 2009) \\
miR126 & Down & (Ahmed et al., 2009) \\
miR-135 & Up & (Koga et al., 2010) \\
miR-143 & Down & (Ahmed et al., 2009, Li et al., 2012) \\
miR-144 & Up & (Kalimutho et al., 2011) \\
miR-145 & Down & (Ahmed et al., 2009, Li et al., 2012) \\
miR-203 & Up & (Ahmed et al., 2009) \\
miR-320 & Down & (Ahmed et al., 2009) \\
miR-326 & Up & (Ahmed et al., 2009) \\
miR-484 & Down & (Ahmed et al., 2009) \\
\hline & & \\
\hline
\end{tabular}

from fluropyrimidine, an adjuvant chemotherapy agent (Nakajima et al., 2006; Diaz et al., 2014).

\section{miRNA-Based Targeted CRC Therapy}

The principle that miRNAs play important roles in CRC development and progression provide a rationale for CRC therapeutic investigations. Tumor suppressor and oncogenic miRNAs, which are so called oncomiRs, hold a promising potential to be manipulated for clinical trials such as CRC treatment, blocking the progression of precursor lesions, prevention of distant metastasis, and improving responses to chemo- and radio-therapies (Tong and Nemunaitis, 2008).

miRNAs interact with different cancer signalling pathways and control cellular homeostasis. Hence, silencing overexpressed oncogenic miRNAs as well as restoring downregulated tumor suppressor miRNAs may eventually lead to the tumor growth and progression inhibition, apoptosis, and reduced cell viability (Du et al., 2014; Orang et al., 2014a).

A wealth of published experiments, some of which have been referenced here, utilized tumor suppressor miRNA recovery methods of CRC treatment (Hu et al., 2010; Liu et al., 2011b; Zhang et al., 2011b). These methods include delivery of miRNA mimics, miRNA precursor, premiRNA and chemically modified oligonucleotides which consequently, abrogate some cancerous characteristics of CRC cell lines (Akao et al., 2006a; Shi et al., 2007; Ng et al., 2009b; Schimanski et al., 2009; Liu et al., 2010, , Nakano et al., 2010; Liu et al., 2011a; Mudduluru et al., 2011). However, in vivo experimental proof is lacking for majority of them.

Negative manipulation of oncogenic miRNAs' 
expression has some similarities with siRNAs in principle and could be achieved through introducing silencing molecules into the cell. Antisense oligonucleotides along with some bearing anchored group, sponge and masking molecules, locked nucleic acid (LNA) are of important miRNA-based therapies. Elaboration of these methods could replace current anticancer therapies and find their ways into daily clinical practices.

On the other hand, the fact that miRNAs need partial sequence complementarity to target mRNA, and consequently could target plethora of mRNAs in a context of a network makes a hindrance to miRNA-based gene therapies, which may lead to toxic phenotype formations in unfavourable cells, off-target effects, and immune system responses. Moreover, rapid degradation of miRNAs or anti-miRNAs by cellular nucleases and poor cellular uptake are another drawback of theses clinical approaches. Therefore, using the lowest optimum concentration of miRNAs along with effective delivery systems such as viral and non-viral vectors and nanoparticles may minimize such side effects and provide dose-dependent accumulation of targeted vectors and nanoparticles in CRC cells.

Considering all together, the miRNA-based gene therapy depends mostly on both positive and negative miRNA expression manipulation. Although there are some administrative obstacles, these therapeutic tools should face a promising future.

\section{Concluding Remarks and Future Challenges}

miRNAs are attracting considerable interest and there are accumulating evidences that aberrant expression of miRNAs plays an important role in CRC development and progression by indirectly changing their plethora of cognate mRNAs, which act either as an oncogene via facilitating tumor initiation and proliferation, or in some cases as a tumor suppressor through inhibiting proliferation and invasion. Significant strengths of miRNA related research are the potential for an important complementary approach to assessing CRC risk, measurement of responses to traditional chemo-and radio-therapies and pharmacologic interventions, and as therapeutic targets for CRC risk and recurrence reduction.

Recently, miRNAs have gained substantial attention as therapeutic targets. Nevertheless, the complexity of gene networks that a single miRNA may control and the potential adverse effects of the miRNA and/or anti-miRNA in vivo deliveries remained to be deeply explored.

In summary, given the ever-expanding number of miRNAs, understanding their functional aspects represents a promising mission. Technologies that integrate RNA sequencing, proteomics, and system biology of gene network will allow a more comprehensive assessment and understanding of miRNA effects and provide exciting opportunities for new pathogenetic and treatment insights into colorectal cancer management. Novel therapeutic strategies will face the major challenge of developing standardized methods for miRNA inhibition that combine high transfection efficiency with targeted delivery.

\section{References}

Ahmed FE, Jeffries CD, Vos PW, et al (2009). Diagnostic microRNA markers for screening sporadic human colon cancer and active ulcerative colitis in stool and tissue. Cancer Genomics Proteomics, 6, 281-95.

Akao Y, Nakagawa Y, Naoe T (2006a). let-7 microRNA functions as a potential growth suppressor in human colon cancer cells. Biol Pharm Bull, 29, 903-6.

Akao Y, Nakagawa Y, Naoe T (2006b). MicroRNAs 143 and 145 are possible common onco-microRNAs in human cancers. Oncol Rep, 16, 845-50.

Akcakaya P, Ekelund S, Kolosenko I, et al (2011). miR-185 and miR-133b deregulation is associated with overall survival and metastasis in colorectal cancer. Int J Oncol, 39, 311-8.

Amodeo V, Bazan V, Fanale D, et al (2013). Effects of antimiR-182 on TSP-1 expression in human colon cancer cells: there is a sense in antisense? Expert Opin Ther Targets, 17, 1249-61.

Arndt GM, Dossey L, Cullen LM, et al (2009). Characterization of global microRNA expression reveals oncogenic potential of miR-145 in metastatic colorectal cancer. BMC Cancer, 9, 374 .

Asangani IA, Rasheed SA, Nikolova DA, et al (2008). MicroRNA-21 (miR-21) post-transcriptionally downregulates tumor suppressor Pded4 and stimulates invasion, intravasation and metastasis in colorectal cancer. Oncogene, 27, 2128-36.

Balaguer F, Link A, Lozano JJ, et al (2010). Epigenetic silencing of miR-137 is an early event in colorectal carcinogenesis. Cancer Res, 70, 6609-18.

Balaguer F, Moreira L, Lozano JJ, et al (2011). Colorectal cancers with microsatellite instability display unique miRNA profiles. Clin Cancer Res, 17, 6239-49.

Bandres E, Agirre X, Bitarte N, et al (2009a). Epigenetic regulation of microRNA expression in colorectal cancer. Int J Cancer, 125, 2737-43.

Bandres E, Bitarte N, Arias F, et al (2009b). microRNA-451 regulates macrophage migration inhibitory factor production and proliferation of gastrointestinal cancer cells. Clin Cancer Res, 15, 2281-90.

Bandrés E, Cubedo E, Agirre X, et al (2006). Identification by Real-time PCR of 13 mature microRNAs differentially expressed in colorectal cancer and non-tumoral tissues. Mol Cancer, 5, 29.

Baraniskin A, Birkenkamp-Demtroder K, Maghnouj A, et al (2012). MiR-30a-5p suppresses tumor growth in colon carcinoma by targeting DTL. Carcinogenesis, 33, 732-9.

Bartel DP (2004). MicroRNAs: genomics, biogenesis, mechanism, and function. Cell, 116, 281-97.

Bitarte N, Bandres E, Boni V (2011). MicroRNA-451 is involved in the self-renewal, tumorigenicity, and chemoresistance of colorectal cancer stem cells. Stem Cells, 29, 1661-71.

Boni V, Bitarte N, Cristobal I, et al (2010). miR-192/miR215 influence 5 -fluorouracil resistance through cell cycle-mediated mechanisms complementary to its posttranscriptional thymidilate synthase regulation. Mol Cancer Ther, 9, 2265-75.

Bovell LC, Shanmugam C, Putcha BD, et al (2013). The prognostic value of microRNAs varies with patient race/ ethnicity and stage of colorectal cancer. Clin Cancer Res, 19, 3955-65.

Braun CJ, Zhang X, Savelyeva I, et al (2008). p53-Responsive micrornas 192 and 215 are capable of inducing cell cycle arrest. Cancer Res, 68, 10094-104.

Burk U, Schubert J, Wellner U, et al (2008). A reciprocal repression between ZEB1 and members of the miR-200 
family promotes EMT and invasion in cancer cells. $E M B O$ Rep, 9, 582-9.

Catela Ivkovic T, Aralica G, Cacev T, Loncar B, Kapitanovic S (2013). miR-106a overexpression and pRB downregulation in sporadic colorectal cancer. Exp Mol Pathol, 94, 148-54.

Cekaite L, Rantala JK, Bruun J (2012). MiR-9, -31, and -182 deregulation promote proliferation and tumor cell survival in colon cancer. Neoplasia, 14, 868-79.

Chandramouli A, Onyeagucha BC, Mercado-Pimentel ME (2012). MicroRNA-101 (miR-101) post-transcriptionally regulates the expression of EP4 receptor in colon cancers. Cancer Biol Ther, 13, 175-83.

Chen DT, Hernandez JM, Shibata D, et al (2012a).Complementary strand microRNAs mediate acquisition of metastatic potential in colonic adenocarcinoma. J Gastrointest Surg, 16, 905-12.

Chen HY, Lin YM, Chung HC, et al (2012b). miR-103/107 promote metastasis of colorectal cancer by targeting the metastasis suppressors DAPK and KLF4. Cancer Res, $\mathbf{7 2}$, 3631-41.

Chen J, Wang W, Zhang Y, Hu T, Chen Y (2014a). The roles of miR-200c in colon cancer and associated molecular mechanisms. Tumour Biol.

Chen JF, Mandel EM, Thomson JM, et al (2006). The role of microRNA-1 and microRNA-133 in skeletal muscle proliferation and differentiation. Nat Genet, 38, 228-33.

Chen ML, Liang LS, Wang XK (2012c). miR-200c inhibits invasion and migration in human colon cancer cells SW480/620 by targeting ZEB1. Clin Exp Metastasis, 29, 457-69.

Chen Q, Xia HW, Ge XJ, et al (2013). Serum miR-19a predicts resistance to FOLFOX chemotherapy in advanced colorectal cancer cases. Asian Pac J Cancer Prev, 14, 7421-6.

Chen T, Yao LQ, Shi Q, et al (2014b). MicroRNA-31 contributes to colorectal cancer development by targeting factor inhibiting HIF-1alpha (FIH-1). Cancer Biol Ther, 15, 516-23.

Chen X, Ba Y, Ma L, et al (2008). Characterization of microRNAs in serum: a novel class of biomarkers for diagnosis of cancer and other diseases. Cell Res, 18, 997-1006.

Chen X, Guo X, Zhang H, et al (2009). Role of miR-143 targeting KRAS in colorectal tumorigenesis. Oncogene, 28, 1385-92.

Cheng AM, Byrom MW, Shelton J, Ford LP (2005). Antisense inhibition of human miRNAs and indications for an involvement of miRNA in cell growth and apoptosis. Nucleic Acids Res, 33, 1290-7.

Cheng H, Zhang L, Cogdell DE, et al (2011). Circulating plasma MiR-141 is a novel biomarker for metastatic colon cancer and predicts poor prognosis. PLoS One, 6, 17745.

Chiang Y, Song Y, Wang Z, et al (2011). Aberrant expression of miR-203 and its clinical significance in gastric and colorectal cancers. J Gastrointest Surg, 15, 63-70.

Chim SS, Shing TK, Hung EC, et al (2008). Detection and characterization of placental microRNAs in maternal plasma. Clin Chem, 54, 482-90.

Cottonham CL, Kaneko S, Xu L (2010). miR-21 and miR-31 converge on TIAM1 to regulate migration and invasion of colon carcinoma cells. J Biol Chem, 285, 35293-302.

Croce CM, Calin GA (2005). miRNAs, cancer, and stem cell division. Cell, 122, 6-7.

Cummins JM, He Y, Leary RJ, et al (2006). The colorectal microRNAome. Proc Natl Acad Sci USA, 103, 3687-92.

Diaz R, Silva J, Garcia JM, et al (2008). Deregulated expression of miR-106a predicts survival in human colon cancer patients. Genes Chromosomes Cancer, 47, 794-802.

Diaz T, Tejero R, Moreno I, et al (2014). Role of miR-200 family members in survival of colorectal cancer patients treated with fluoropyrimidines. J Surg Oncol, 109, 676-83.

Diosdado B, van de Wiel MA, Terhaar Sive Droste JS, et al (2009). MiR-17-92 cluster is associated with $13 q$ gain and c-myc expression during colorectal adenoma to adenocarcinoma progression. Br J Cancer, 101, 707-14.

$\mathrm{Du}$ W, Ma XL, Zhao C, et al (2014). Associations of single nucleotide polymorphisms in miR-146a, miR-196a, miR-149 and miR-499 with colorectal cancer susceptibility. Asian Pac $J$ Cancer Prev, 15, 1047-55.

Earle JS, Luthra R, Romans A, et al (2010). Association of microRNA expression with microsatellite instability status in colorectal adenocarcinoma. J Mol Diagn, 12, 433-40.

Esquela-Kerscher A, Slack FJ (2006). Oncomirs - microRNAs with a role in cancer. Nat Rev Cancer, 6, 259-69.

Fang WJ, Lin CZ, Zhang HH, et al (2007). Detection of let-7a microRNA by real-time PCR in colorectal cancer: a singlecentre experience from China. J Int Med Res, 35, 716-23.

Feng B, Dong TT, Wang LL, et al (2012). Colorectal cancer migration and invasion initiated by microRNA-106a. PLoS One, 7, 43452 .

Filipowicz W (2005). RNAi: the nuts and bolts of the RISC machine. Cell, 122, 17-20.

Geng L, Chaudhuri A, Talmon G, et al (2013). MicroRNA-192 suppresses liver metastasis of colon cancer. Oncogene.

Grady WM, Parkin RK, Mitchell PS, et al (2008). Epigenetic silencing of the intronic microRNA hsa-miR-342 and its host gene EVL in colorectal cancer. Oncogene, 27, 3880-8.

Guo H, Hu X, Ge S, Qian G, Zhang J (2012). Regulation of RAP1B by miR-139 suppresses human colorectal carcinoma cell proliferation. Int J Biochem Cell Biol, 44, 1465-72.

Guo ST, Jiang CC, Wang GP, et al (2013). MicroRNA-497 targets insulin-like growth factor 1 receptor and has a tumour suppressive role in human colorectal cancer. Oncogene, 32, 1910-20.

Haghighi MM, Javadi GR, Parivar K, et al (2010). Frequent MSI mononucleotide markers for diagnosis of hereditary nonpolyposis colorectal cancer. Asian Pac J Cancer Prev, 11, 1033-5.

Han HB, Gu J, Zuo HJ, et al (2012). Let-7c functions as a metastasis suppressor by targeting MMP11 and PBX3 in colorectal cancer. $J$ Pathol, 226, 544-55.

Hatfield SD, Shcherbata HR, Fischer KA, et al (2005). Stem cell division is regulated by the microRNA pathway. Nature, 435, 974-8.

He X, Dong Y, Wu CW, et al (2012). MicroRNA-218 inhibits cell cycle progression and promotes apoptosis in colon cancer by downregulating BMI1 polycomb ring finger oncogene. Mol Med, 18, 1491-8.

Hofsli E, Sjursen W, Prestvik WS, et al (2013). Identification of serum microRNA profiles in colon cancer. Br J Cancer, 108, 1712-9.

Hu G, Chen D, Li X, et al (2010). miR-133b regulates the MET proto-oncogene and inhibits the growth of colorectal cancer cells in vitro and in vivo. Cancer Biol Ther, 10, 190-7.

Huang Q, Gumireddy K, Schrier M, et al (2008). The microRNAs miR-373 and miR-520c promote tumour invasion and metastasis. Nat Cell Biol, 10, 202-10.

Huang Z, Huang D, Ni S, et al (2010). Plasma microRNAs are promising novel biomarkers for early detection of colorectal cancer. Int J Cancer, 127, 118-26.

Huang Z, Huang S, Wang Q, et al (2011). MicroRNA-95 promotes cell proliferation and targets sorting Nexin 1 in human colorectal carcinoma. Cancer Res, 71, 2582-9.

Hummel R, Hussey DJ, Haier J (2010). MicroRNAs: predictors and modifiers of chemo- and radiotherapy in different tumour types. Eur J Cancer, 46, 298-311.

Hur K, Toiyama Y, Takahashi M, et al (2013). MicroRNA-200c 
Ayla Valinezhad Orang and Abolfazl Barzegari

modulates epithelial-to-mesenchymal transition (EMT) in human colorectal cancer metastasis. Gut, 62, 1315-26.

Ivanovska I, Ball AS, Diaz RL, et al (2008). MicroRNAs in the miR-106b family regulate $\mathrm{p} 21 / \mathrm{CDKN} 1 \mathrm{~A}$ and promote cell cycle progression. Mol Cell Biol, 28, 2167-74.

Jahid S, Sun J, Edwards RA, et al (2012). miR-23a promotes the transition from indolent to invasive colorectal cancer. Cancer Discov, 2, 540-53.

Jamshidi-Adegani F, Langroudi L, Shafiee A, at al (2014). Mir302 cluster exhibits tumor suppressor properties on human unrestricted somatic stem cells. Tumour Biol.

Johnston RJ, Hobert O (2003). A microRNA controlling left/ right neuronal asymmetry in caenorhabditis elegans. Nature, 426, 845-9.

Josse C, Bouznad N, Geurts P, et al (2014). Identification of a microRNA landscape targeting the PI3K/Akt signaling pathway in inflammation-induced colorectal carcinogenesis. Am J Physiol Gastrointest Liver Physiol, 306, 229-43.

Kalimutho M, Del Vecchio Blanco G, Di Cecilia S, et al (2011). Differential expression of miR-144* as a novel fecal-based diagnostic marker for colorectal cancer. J Gastroenterol, 46, 1391-402.

Kanaan Z, Rai SN, Eichenberger MR, et al (2012). Plasma miR21: a potential diagnostic marker of colorectal cancer. Ann Surg, 256, 544-51.

Karaayvaz M, Pal T, Song B, at al (2011). Prognostic significance of miR-215 in colon cancer. Clin Colorectal Cancer, 10, 340-7.

Koga Y, Yamazaki N, Yamamoto Y, at al (2013). Fecal miR-106a is a useful marker for colorectal cancer patients with falsenegative results in immunochemical fecal occult blood test. Cancer Epidemiol Biomarkers Prev, 22, 1844-52.

Koga Y, Yasunaga M, Takahashi A, at al (2010). MicroRNA expression profiling of exfoliated colonocytes isolated from feces for colorectal cancer screening. Cancer Prev Res (Phila), 3, 1435-42.

Kulda V, Pesta M, Topolcan O, at al (2010). Relevance of miR21 and miR-143 expression in tissue samples of colorectal carcinoma and its liver metastases. Cancer Genet Cytogenet, 200, 154-60.

Kunte DP, DelaCruz M, Wali RK, et al (2012). Dysregulation of microRNAs in colonic field carcinogenesis: implications for screening. PLoS One, 7, 45591.

Kurokawa K, Tanahashi T, Iima T, et al (2012). Role of miR-19b and its target mRNAs in 5-fluorouracil resistance in colon cancer cells. J Gastroenterol, 47, 883-95.

Lanza G, Ferracin M, Gafa R, et al (2007). mRNA/microRNA gene expression profile in microsatellite unstable colorectal cancer. Mol Cancer, 6, 54.

Lawrie CH, Gal S, Dunlop HM, et al (2008). Detection of elevated levels of tumour-associated microRNAs in serum of patients with diffuse large B-cell lymphoma. Br J Haematol, 141, 672-5.

Lee JK, Liles EG, Bent S, Levin TR, Corley DA (2014). Accuracy of fecal immunochemical tests for colorectal cancer: systematic review and meta-analysis. Ann Intern Med, 160, 171 .

Lewis BP, Burge CB, Bartel DP (2005). Conserved seed pairing, often flanked by adenosines, indicates that thousands of human genes are microRNA targets. Cell, 120, 15-20.

Li HY, Zhang Y, Cai JH, Bian HL (2013). MicroRNA-451 inhibits growth of human colorectal carcinoma cells via downregulation of Pi3k/Akt pathway. Asian Pac J Cancer Prev, 14, 3631-4.

Li J, Chen Y, Zhao J, Kong F, Zhang Y (2011). miR-203 reverses chemoresistance in p53-mutated colon cancer cells through downregulation of Akt2 expression. Cancer Lett, 304,52-9.
Li JM, Zhao RH, Li ST, at al (2012). Down-regulation of fecal miR-143 and miR-145 as potential markers for colorectal cancer. Saudi Med J, 33, 24-9.

Li T, Yang J, Lv X, at al (2014a). miR-155 regulates the proliferation and cell cycle of colorectal carcinoma cells by targeting E2F2. Biotechnol Lett.

Li Y, Li Y, Liu Y, at al (2014b). PAX6, a novel target of microRNA-7, promotes cellular proliferation and invasion in human colorectal cancer cells. Dig Dis Sci, 59, 598-606.

Li YJ, Zhang ZY, Mao YY, et al (2014c). A genetic variant in MiR-146a modifies digestive system cancer risk: a metaanalysis. Asian Pac J Cancer Prev, 15, 145-50.

Link A, Balaguer F, Shen Y, at al (2010). Fecal MicroRNAs as novel biomarkers for colon cancer screening. Cancer Epidemiol Biomarkers Prev, 19, 1766-74.

Liu L, Chen L, Xu Y, Li R, Du X (2010). microRNA-195 promotes apoptosis and suppresses tumorigenicity of human colorectal cancer cells. Biochem Biophys Res Commun, 400, 236-40.

Liu M, Lang N, Chen X, at al (2011a). miR-185 targets RhoA and $\mathrm{Cdc} 42$ expression and inhibits the proliferation potential of human colorectal cells. Cancer Lett, 301, 151-60.

Liu M, Lang N, Qiu M, at al (2011b). miR-137 targets Cdc42 expression, induces cell cycle $\mathrm{G} 1$ arrest and inhibits invasion in colorectal cancer cells. Int J Cancer, 128, 1269-79.

Long L, Huang G, Zhu H, at al (2013). Down-regulation of miR-138 promotes colorectal cancer metastasis via directly targeting TWIST2. J Transl Med, 11, 275.

Lu YX, Yuan L, Xue XL, at al (2014). Regulation of colorectal carcinoma stemness, growth, and metastasis by an miR200c-Sox2-negative feedback loop mechanism. Clin Cancer Res, 20, 2631-42.

Lujambio A, Calin GA, Villanueva A, at al (2008). A microRNA DNA methylation signature for human cancer metastasis. Proc Natl Acad Sci U S A, 105, 13556-61.

Ma Q, Wang X, Li Z, at al (2013). microRNA-16 represses colorectal cancer cell growth in vitro by regulating the p53/ survivin signaling pathway. Oncol Rep, 29, 1652-8.

Matsushima K, Isomoto H, Yamaguchi N, at al (2011). MiRNA-205 modulates cellular invasion and migration via regulating zinc finger E-box binding homeobox 2 expression in esophageal squamous cell carcinoma cells. J Transl Med, $\mathbf{9}, 30$.

Michael MZ, O' Connor SM, van Holst Pellekaan NG, Young GP, James RJ (2003). Reduced accumulation of specific microRNAs in colorectal neoplasia. Mol Cancer Res, $\mathbf{1}$, 882-91.

Mishra PJ, Song B, Mishra PJ, at al (2009). MiR-24 tumor suppressor activity is regulated independent of p53 and through a target site polymorphism. PLoS One, 4, 8445.

Mitchell PS, Parkin RK, Kroh EM, at al (2008). Circulating microRNAs as stable blood-based markers for cancer detection. Proc Natl Acad Sci U S A, 105, 10513-8.

Mollaie HR, Monavari SH, Arabzadeh SA, at al (2013). RNAi and miRNA in viral infections and cancers. Asian Pac $J$ Cancer Prev, 14, 7045-56.

Motoyama K, Inoue H, Takatsuno Y, at al (2009). Over- and under-expressed microRNAs in human colorectal cancer. Int J Oncol, 34, 1069-75.

Mudduluru G, Ceppi P, Kumarswamy R, at al (2011). Regulation of Axl receptor tyrosine kinase expression by miR-34a and miR-199a/b in solid cancer. Oncogene, 30, 2888-99.

Naguibneva I, Ameyar-Zazoua M, Polesskaya A, at al (2006). The microRNA miR-181 targets the homeobox protein Hox-A11 during mammalian myoblast differentiation. Nat Cell Biol, 8, 278-84.

Nakajima G, Hayashi K, Xi Y, at al (2006). Non-coding 
MicroRNAs hsa-let-7g and hsa-miR-181b are associated with chemoresponse to S-1 in colon cancer. Cancer Genomics Proteomics, 3, 317-24.

Nakano H, Miyazawa T, Kinoshita K, Yamada Y, Yoshida T )2010(. Functional screening identifies a microRNA, miR-491 that induces apoptosis by targeting Bcl-X(L) in colorectal cancer cells. Int J Cancer, 127, 1072-80.

Narasimhan K, Gauthaman K, Natesan P, et al (2014). Identification of unique miRNA biomarkers in colorectal adenoma and carcinoma using microarray: evaluation of their putative role in disease progression. ISRN Cell Biol, 2014.

$\mathrm{Ng}$ EK, Chong WW, Jin H, et al (2009a). Differential expression of microRNAs in plasma of patients with colorectal cancer: a potential marker for colorectal cancer screening. Gut, $\mathbf{5 8}$, 1375-81.

Ng EK, Tsang WP, Ng SS, et al (2009b). MicroRNA-143 targets DNA methyltransferases $3 \mathrm{~A}$ in colorectal cancer. $\mathrm{Br}$ J Cancer, 101, 699-706.

Nishida N, Yamashita S, Mimori K, at al (2012). MicroRNA-10b is a prognostic indicator in colorectal cancer and confers resistance to the chemotherapeutic agent 5-fluorouracil in colorectal cancer cells. Ann Surg Oncol, 19, 3065-71.

Nishida N, Yokobori T, Mimori K, et al (2011). MicroRNA miR$125 \mathrm{~b}$ is a prognostic marker in human colorectal cancer. Int J Oncol, 38, 1437-43.

Nugent M, Miller N, Kerin MJ (2012). Circulating miR-34a levels are reduced in colorectal cancer. J Surg Oncol, 106, 947-52.

Ogata-Kawata H, Izumiya M, Kurioka D, et al (2014). Circulating exosomal microRNAs as biomarkers of colon cancer. PLoS One, 9, 92921.

Olaru AV, Selaru FM, Mori Y, at al (2011). Dynamic changes in the expression of MicroRNA-31 during inflammatory bowel disease-associated neoplastic transformation. Inflamm Bowel Dis, 17, 221-31.

Orang AV, Safaralizadeh R, Hosseinpour Feizi MA (2014a). Insights into the diverse roles of miR-205 in human cancers. Asian Pac J Cancer Prev, 15, 577-83.

Orang AV, Safaralizadeh R, Hosseinpour Feizi MA, Somi MH (2014b). Diagnostic and prognostic value of miR-205 in colorectal cancer. Asian Pac J Cancer Prev, 15, 4033-7.

Park SY, Kim H, Yoon S, et al (2014). KITENIN-targeting microRNA-124 suppresses colorectal cancer cell motility and tumorigenesis. Mol Ther.

Pichler M, Winter E, Ress AL, et al (2014). miR-181a is associated with poor clinical outcome in patients with colorectal cancer treated with EGFR inhibitor. J Clin Pathol, 67, 198-203.

Poudyal D, Cui X, Le PM, et al (2013). A key role of microRNA$29 \mathrm{~b}$ for the suppression of colon cancer cell migration by American ginseng. PLoS One, 8, 75034.

Pourhoseingholi MA (2012). Increased burden of colorectal cancer in Asia. World J Gastrointest Oncol, 4, 68-70.

Poy MN, Eliasson L, Krutzfeldt J, et al (2004). A pancreatic islet-specific microRNA regulates insulin secretion. Nature, 432, 226-30.

Pu XX, Huang GL, Guo HQ, et al (2010). Circulating miR-221 directly amplified from plasma is a potential diagnostic and prognostic marker of colorectal cancer and is correlated with 553 expression. J Gastroenterol Hepatol, 25, 1674-80.

Qin S, Zhu Y, Ai F, et al (2014). MicroRNA-191 correlates with poor prognosis of colorectal carcinoma and plays multiple roles by targeting tissue inhibitor of metalloprotease 3 . Neoplasma, 61, 27-34.

Qu A, Du L, Yang Y, et al (2014). Hypoxia-Inducible MiR210 is an independent prognostic factor and contributes to metastasis in colorectal Cancer. PLoS One, 9, 90952.
Ragusa M, Statello L, Maugeri M, et al (2012). Specific alterations of the microRNA transcriptome and global network structure in colorectal cancer after treatment with MAPK/ERK inhibitors. J Mol Med (Berl), 90, 1421-38.

Reid JF, Sokolova V, Zoni E, et al (2012). miRNA profiling in colorectal cancer highlights miR-1 involvement in METdependent proliferation. Mol Cancer Res, 10, 504-15.

Rossi L, Bonmassar E, Faraoni I (2007). Modification of miR gene expression pattern in human colon cancer cells following exposure to 5-fluorouracil in vitro. Pharmacol Res, 56, 248-53.

Saito Y, Liang G, Egger G, et al (2006). Specific activation of microRNA-127 with downregulation of the proto-oncogene BCL6 by chromatin-modifying drugs in human cancer cells. Cancer Cell, 9, 435-43.

Salimzadeh H, Delavari A, Montazeri A, Mirzazadeh A (2012). Knowledge and practice of iranians toward colorectal cancer, and barriers to screening. Int J Prev Med, 3, 29-35.

Sarver AL, French AJ, Borralho PM, et al (2009). Human colon cancer profiles show differential microRNA expression depending on mismatch repair status and are characteristic of undifferentiated proliferative states. BMC Cancer, 9, 401 .

Sarver AL, Li L, Subramanian S (2010). MicroRNA miR-183 functions as an oncogene by targeting the transcription factor EGR1 and promoting tumor cell migration. Cancer Res, 70, 9570-80.

Schepeler T, Holm A, Halvey P, et al (2012). Attenuation of the beta-catenin/TCF4 complex in colorectal cancer cells induces several growth-suppressive microRNAs that target cancer promoting genes. Oncogene, 31, 2750-60.

Schepeler T, Reinert JT, Ostenfeld MS, et al (2008). Diagnostic and prognostic microRNAs in stage II colon cancer. Cancer Res, 68, 6416-24.

Schetter AJ, Leung SY, Sohn JJ, et al (2008). MicroRNA expression profiles associated with prognosis and therapeutic outcome in colon adenocarcinoma. JAMA, 299, 425-36.

Schimanski CC, Frerichs K, Rahman F, et al (2009). High miR196a levels promote the oncogenic phenotype of colorectal cancer cells. World J Gastroenterol, 15, 2089-96.

Seton-Rogers S (2013). Non-coding RNAs: The cancer X factor. Nat Rev Cancer, 13, 224-5.

Shemirani AI, Haghighi MM, Zadeh SM, et al (2011). Simplified MSI marker panel for diagnosis of colorectal cancer. Asian Pac J Cancer Prev, 12, 2101-4.

Shen K, Liang Q, Xu K, et al (2012). MiR-139 inhibits invasion and metastasis of colorectal cancer by targeting the type I insulin-like growth factor receptor. Biochem Pharmacol, 84, 320-30.

Shi B, Sepp-Lorenzino L, Prisco M, et al (2007). Micro RNA 145 targets the insulin receptor substrate- 1 and inhibits the growth of colon cancer cells. J Biol Chem, 282, 32582-90.

Shivapurkar N, Mikhail S, Navarro R, et al (2013). Decrease in blood miR-296 predicts chemotherapy resistance and poor clinical outcome in patients receiving systemic chemotherapy for metastatic colon cancer. Int J Colorectal Dis, 28, 887.

Siegel R, Naishadham D, Jemal A (2012). Cancer statistics, 2012. CA Cancer J Clin, 62, 10-29.

Slaby O, Svoboda M, Fabian P, et al (2007). Altered expression of miR-21, miR-31, miR-143 and miR-145 is related to clinicopathologic features of colorectal cancer. Oncology, 72, 397-402.

Slattery ML, Wolff E, Hoffman MD, et al (2011). MicroRNAs and colon and rectal cancer: differential expression by tumor location and subtype. Genes Chromosomes Cancer, 50, 196-206.

Song B, Wang Y, Kudo K, et al (2008). miR-192 Regulates 
Ayla Valinezhad Orang and Abolfazl Barzegari

dihydrofolate reductase and cellular proliferation through the p53-microRNA circuit. Clin Cancer Res, 14, 8080-6.

Tagawa T, Haraguchi T, Hiramatsu H, et al (2012). Multiple microRNAs induced by $\mathrm{Cdx} 1$ suppress $\mathrm{Cdx} 2$ in human colorectal tumour cells. Biochem J, 447, 449-55.

Tan YG, Zhang YF, Guo CJ, Yang M, Chen MY (2013). Screening of differentially expressed microRNA in ulcerative colitis related colorectal cancer. Asian Pac J Trop Med, 6, 972-6.

Tang W, Zhu Y, Gao J, et al (2014). MicroRNA-29a promotes colorectal cancer metastasis by regulating matrix metalloproteinase 2 and E-cadherin via KLF4. Br J Cancer, 110, 450-8.

Taylor DD, Gercel-Taylor C (2008). MicroRNA signatures of tumor-derived exosomes as diagnostic biomarkers of ovarian cancer. Gynecol Oncol, 110, 13-21.

Terzić J, Grivennikov S, Karin E, Karin M (2010). Inflammation and colon cancer. Gastroenterology, 138, 2101-14.

Tong AW, Nemunaitis J (2008). Modulation of miRNA activity in human cancer: a new paradigm for cancer gene therapy? Cancer Gene Ther, 15, 341-55.

Tsuchida A, Ohno S, Wu W, et al (2011). miR-92 is a key oncogenic component of the miR-17-92 cluster in colon cancer. Cancer Sci, 102, 2264-71.

Tsunoda T, Takashima Y, Yoshida Y, et al (2011). Oncogenic KRAS regulates miR-200c and miR-221/222 in a 3D-specific manner in colorectal cancer cells. Anticancer Res, 31, 24539.

Valeri N, Braconi C, Gasparini P, et al (2014). MicroRNA-135b promotes cancer progression by acting as a downstream effector of oncogenic pathways in colon cancer. Cancer Cell, 25, 469-83.

Valeri N, Gasparini P, Braconi C, et al (2010a). MicroRNA-21 induces resistance to 5-fluorouracil by down-regulating human DNA MutS homolog 2 (hMSH2). Proc Natl Acad Sci USA, 107, 21098-103.

Valeri N, Gasparini P, Fabbri M, et al (2010b). Modulation of mismatch repair and genomic stability by miR-155. Proc Natl Acad Sci U S A, 107, 6982-7.

Vogelstein B, Fearon ER, Hamilton SR, et al (1988). Genetic alterations during colorectal-tumor development. $N$ Engl $J$ Med, 319, 525-32.

Volinia S, Calin GA, Liu CG, et al (2006). A microRNA expression signature of human solid tumors defines cancer gene targets. Proc Natl Acad Sci U S A, 103, 2257-61.

Wang B, Zhang Q (2012). The expression and clinical significance of circulating microRNA-21 in serum of five solid tumors. J Cancer Res Clin Oncol, 138, 1659-66.

Wang CJ, Zhou ZG, Wang L, et al (2009). Clinicopathological significance of microRNA-31,-143 and -145 expression in colorectal cancer. Dis Markers, 26, 27-34.

Wang F, Zhang P, Ma Y,et al (2012a). NIRF is frequently upregulated in colorectal cancer and its oncogenicity can be suppressed by let-7a microRNA. Cancer Lett, 314, 223-31.

Wang H, An H, Wang B, et al (2013). miR-133a represses tumour growth and metastasis in colorectal cancer by targeting LIM and SH3 protein 1 and inhibiting the MAPK pathway. Eur J Cancer, 49, 3924-35.

Wang H, Wu J, Meng X, et al (2011). MicroRNA-342 inhibits colorectal cancer cell proliferation and invasion by directly targeting DNA methyltransferase 1. Carcinogenesis, 32, 1033-42.

Wang Q, Huang Z, Ni S, et al (2012b). Plasma miR-601 and miR-760 are novel biomarkers for the early detection of colorectal cancer. PLoS One, 7, 44398.

Wang X, Wang J, MaH,Zhang J,Zhou X (2012c). Downregulation of miR-195 correlates with lymph node metastasis and poor prognosis in colorectal cancer. Med Oncol, 29, 919-27.
Wang YX, Zhang XY, Zhang BF, et al (2010). Initial study of microRNA expression profiles of colonic cancer without lymph node metastasis. J Dig Dis, 11, 50-4.

Weng L, Wu X, Gao H, et al (2010). MicroRNA profiling of clear cell renal cell carcinoma by whole-genome small RNA deep sequencing of paired frozen and formalin-fixed, paraffin-embedded tissue specimens. J Pathol, 222, 41-51.

Wu CW, Dong YJ, Liang QY, et al (2013a). MicroRNA-18a attenuates DNA damage repair through suppressing the expression of ataxia telangiectasia mutated in colorectal cancer. PLoS One, 8, 57036.

Wu CW, Ng SS, Dong YJ, et al (2012a). Detection of miR92a and miR-21 in stool samples as potential screening biomarkers for colorectal cancer and polyps. Gut, 61, 739-45.

Wu L, Li H, Jia CY, et al (2012b). MicroRNA-223 regulates FOXO1 expression and cell proliferation. FEBS Lett, 586, 1038-43.

Wu W, Yang J, Feng X, et al (2013b). MicroRNA-32 (miR32) regulates phosphatase and tensin homologue (PTEN) expression and promotes growth, migration, and invasion in colorectal carcinoma cells. Mol Cancer, 12, 30.

Xi Y, Formentini A, Chien M, et al (2006). Prognostic values of microRNAs in colorectal cancer. Biomark Insights, 2 , 113-21.

Xi Y, Nakajima G, Gavin E, et al (2007). Systematic analysis of microRNA expression of RNA extracted from fresh frozen and formalin-fixed paraffin-embedded samples. Rna, 13, 1668-74.

Xiang KM, Li XR (2014). MiR-133b acts as a tumor suppressor and negatively regulates TBPL1 in colorectal cancer cells. Asian Pac J Cancer Prev, 15, 3767-72.

Xie Y, Xiao G, Coombes KR, et al (2011). Robust gene expression signature from formalin-fixed paraffin-embedded samples predicts prognosis of non-small-cell lung cancer patients. Clin Cancer Res, 17, 5705-14.

Xu K, Chen Z, Qin C, Song X (2014). miR-7 inhibits colorectal cancer cell proliferation and induces apoptosis by targeting XRCC2. Onco Targets Ther, 7, 325-32.

Xu K, Liang X, Shen K, et al (2012a). MiR-222 modulates multidrug resistance in human colorectal carcinoma by down-regulating ADAM-17. Exp Cell Res, 318, 2168-77.

Xu XM, Qian JC, Deng ZL, et al (2012b). Expression of miR-21, miR-31, miR-96 and miR-135b is correlated with the clinical parameters of colorectal cancer. Oncol Lett, 4, 339-345.

Yadav NK, Shukla P, Omer A, Pareek S, Singh RK (2014). Next Generation Sequencing: Potential and Application in Drug Discovery. ScientificWorld Journal, 2014, 802437.

Yamada N, Nakagawa Y, Tsujimura N, et al (2013). Role of intracellular and extracellular microRNA-92a in colorectal cancer. Transl Oncol, 6, 482-92.

Yamamichi N, Shimomura R, Inada K, et al (2009). Locked nucleic acid in situ hybridization analysis of miR-21 expression during colorectal cancer development. Clin Cancer Res, 15, 4009-16.

Yamashita S, Yamamoto H, Mimori K, et al (2012). MicroRNA-372 is associated with poor prognosis in colorectal cancer. Oncology, 82, 205-12.

Yan H, Choi AJ, Lee BH, Ting AH (2011). Identification and functional analysis of epigenetically silenced microRNAs in colorectal cancer cells. PLoS One, 6, 20628.

Yang IP, Tsai HL, Hou MF, et al (2012). MicroRNA-93 inhibits tumor growth and early relapse of human colorectal cancer by affecting genes involved in the cell cycle. Carcinogenesis, 33, 1522-30.

Yantiss RK, Goodarzi M, Zhou XK, et al (2009). Clinical, pathologic, and molecular features of early-onset colorectal carcinoma. Am J Surg Pathol, 33, 572-82. 
Yu G, Li H, Wang X, et al (2013a). MicroRNA-19a targets tissue factor to inhibit colon cancer cells migration and invasion. Mol Cell Biochem, 380, 239-47.

Yu H, Gao G, Jiang L, et al (2013b). Decreased expression of miR-218 is associated with poor prognosis in patients with colorectal cancer. Int J Clin Exp Pathol, 6, 2904-11.

Yu XF, Zou J, Bao ZJ, Dong J (2011). miR-93 suppresses proliferation and colony formation of human colon cancer stem cells. World J Gastroenterol, 17, 4711-7.

Yuan K, Xie K, Fox J, et al (2013). Decreased levels of miR224 and the passenger strand of miR-221 increase MBD2, suppressing maspin and promoting colorectal tumor growth and metastasis in mice. Gastroenterology, 145, 853-64.

Zhang BG, Li JF, Yu BQ, et al (2012). microRNA-21 promotes tumor proliferation and invasion in gastric cancer by targeting PTEN. Oncol Rep, 27, 1019-26.

Zhang GJ, Xiao HX, Tian HP, et al (2013a). Upregulation of microRNA-155 promotes the migration and invasion of colorectal cancer cells through the regulation of claudin-1 expression. Int J Mol Med, 31, 1375-80.

Zhang GJ, Zhou H, Xiao HX, Li Y, Zhou T (2013b). Upregulation of miR-224 promotes cancer cell proliferation and invasion and predicts relapse of colorectal cancer. Cancer Cell Int, 13, 104.

Zhang GJ, Zhou H, Xiao HX, Li Y, Zhou T (2014a). MiR-378 is an independent prognostic factor and inhibits cell growth and invasion in colorectal cancer. BMC Cancer, 14, 109.

Zhang H, Li Y, Huang Q, et al (2011a). MiR-148a promotes apoptosis by targeting Bcl-2 in colorectal cancer. Cell Death Differ, 18, 1702-10.

Zhang J, Guo H, Zhang H, et al (2011b). Putative tumor suppressor miR-145 inhibits colon cancer cell growth by targeting oncogene Friend leukemia virus integration 1 gene. Cancer, 117, 86-95.

Zhang N, Li X, Wu CW, et al (2013c). microRNA-7 is a novel inhibitor of YY1 contributing to colorectal tumorigenesis. Oncogene, 32, 5078-88.

Zhang Y,Zheng L, Huang J, et al (2014b). MiR-124 radiosensitizes human colorectal cancer cells by targeting PRRX1. PLoS One, 9, 93917.

Zhao Y, Samal E, Srivastava D (2005). Serum response factor regulates a muscle-specific microRNA that targets Hand2 during cardiogenesis. Nature, 436, 214-20.

Zheng G, Wang H, Zhang X, et al (2013). Identification and validation of reference genes for qPCR detection of serum microRNAs in colorectal adenocarcinoma patients. PLoS One, 8, 83025 .

Zhong M, Bian Z, Wu Z (2013). miR-30a suppresses cell migration and invasion through downregulation of PIK3CD in colorectal carcinoma. Cell Physiol Biochem, 31, 209-18.

Zhou W, Li X, Liu F, et al (2012). MiR-135a promotes growth and invasion of colorectal cancer via metastasis suppressor 1 in vitro. Acta Biochim Biophys Sin (Shanghai), 44, 838-46.

Zhou XJ, Dong ZG, Yang YM, et al (2013a). Limited diagnostic value of microRNAs for detecting colorectal cancer: a metaanalysis. Asian Pac J Cancer Prev, 14, 4699-704.

Zhou Y, Feng X, Liu YL, et al (2013b). Down-regulation of miR126 is associated with colorectal cancer cells proliferation, migration and invasion by targeting IRS- 1 via the AKT and ERK1/2 signaling pathways. PLoS One, $8,81203$.

Zhou Y, Wan G, Spizzo R, et al (2014). miR-203 induces oxaliplatin resistance in colorectal cancer cells by negatively regulating ATM kinase. Mol Oncol, 8, 83-92.

Zhu L, Chen H, Zhou D, et al (2012). MicroRNA-9 up-regulation is involved in colorectal cancer metastasis via promoting cell motility. Med Oncol, 29, 1037-43. 